ORIGINAL PROF-2206

\title{
CESAREAN SECTION;
}

Frequency and fetomaternal morbidity

Dr. Qamarunissa, Dr. Fkharunissa.

ABSTRACT... Study Design: Descriptive observational. Setting: The study was conducted in Gynaecological/Obstetrics department of Isra University Hospital Hyderabad. Duration of study: One year from from1st April 2010 to 1st March 2011. Results: The total numbers of deliveries were 1522 out of them 551 (36.20\%) were cesarean section while 971 (63.79\%) were normal vaginal deliveries. Regarding the age group majority of cases were $241(43.73 \%)$ belongs to 31 to 40 years. In our study majority of cases i.e. $328(59.52 \%)$ were multigravida while $389(70.59 \%)$ cases belongs to low socioeconomic and $422(79.88 \%)$ were unbooked. Regarding indications most of the cesarean section were performed due to obstructed labour and main complication was found after cesarean section was PPH while fetal complication was early neonatal death. Conclusions: The rate of cesarean section in our study was high. The commonest indication of cesarean section was obstructed labour and majority of the patients belongs to low socioeconomic and were unbooked. Common complication was PPH, fever from maternal side while fetal complication was early neonatal death.

Key words: Cesarean section, frequency, fetometernal morbidity.

Article Citation

Qamarunissa, Fkharunissa. Cesarean section; frequency and fetomaternal morbidity. Professional Med J 2013;20(4): 537-541.

\section{INTRODUCTION}

The steadily raising global rate of cesarean section has become one of the most debating topic obstetrics as its prevalence has increased in last few years ${ }^{1,2}$. This is due to cesarean section being performed for breech presentation and fetal distress ${ }^{3}$. Repeat cesarean section contribute to $30 \%$ of all cesarean section ${ }^{4}$. Vaginal birth after one cesarean section is one solution to decrease the rising cesarean section rate .Several suggest that vaginal delivery after one cesarean section is safe ${ }^{4}$.

WHO indicated that a cesarean section rate greater than $10-15 \%$ is not justified in any region of the world ${ }^{5}$. In the recent years the rate has increased to a record level of $46 \%$ in china, and $25 \%$ and above in many Asian countries, Latin American, USA ${ }^{6}$, considering the indication of the repeat cesarean section, dystocia, fetal distress, APH etc are commonly reported in Pakistan studies?.

Cesarean section considered a major surgery and have increase short and long term adverse effect for mother and baby. Major countries of world have recognized high cesarean section rate and they are introducing measures to reduce this rising rate. Laith stated that focus of the study should be indication of cesarean section ${ }^{8}$.

The aim of this study was to know the frequency of cesarean section and fetometernal morbidity.

\section{PATIENTS METHODS}

The descriptive observational study was conducted from $1^{\text {st }}$ April 2010 to $1^{\text {st }}$ March 2011 in Department Gynaecology and Obstetrics at Isra University Hospital Hyderabad.

All women who under went cesarean section were included in study while cases of rupture uterus were excluded from this study. All the information was collected from the clinical record of patient on predesigned proforma. Information regarding the age, socioeconomic, indication of cesarean section and maternal and perinatal morbidity was recorded. Results were analyzed on SPSS version 12. Frequency and percentage were calculated to desirable the results. 


\section{RESULTS}

This descriptive observational study was conducted in the department of obstetrics and gynaecology, Isra University, to know the rate of cesarean section and fetometernal morbidity.

Total 1522 deliveries were conducted in a year from $1^{\text {st }}$ April 2010 to $1^{\text {st }}$ March 2011, out of them $551(36.20 \%)$ were cesarean section while $971(63.79 \%)$ were normal vaginal deliveries.

Cesarean section were further divided into emergency and elective, elective cases were 122(22.1\%) while emergency cases were 429(77.8\%). In our study 241(43.73\% ) patients were belonged to age between 31 to 40 years and $112(20.32 \%)$ patients were less than 20 years age. Regarding the parity $328(59.52 \%)$ patient were multigravida while 142(25.77\%) were primigravida. In our study majority of cases were unbooked and belonged to low socioeconomic. (TableI)

\begin{tabular}{|c|c|c|}
\hline Age & Number & Percentage \\
\hline$<20$ & 112 & $20.32 \%$ \\
\hline 21 to 30 & 128 & $23.23 \%$ \\
\hline 31 to 40 & 241 & $43.73 \%$ \\
\hline$>40$ & 70 & $12.7 \%$ \\
\hline \multicolumn{3}{|l|}{ Parity } \\
\hline Primigravida & 142 & $25.77 \%$ \\
\hline Multigravida & 328 & $59.52 \%$ \\
\hline Grandmulti & 81 & $14.70 \%$ \\
\hline \multicolumn{3}{|l|}{ Socioeconomic } \\
\hline Low & 389 & $70.59 \%$ \\
\hline Middle & 122 & $22.14 \%$ \\
\hline Upper & 40 & $7.25 \%$ \\
\hline \multicolumn{3}{|l|}{ Booking status } \\
\hline Booked & 129 & $23.41 \%$ \\
\hline Unbooked & 422 & $76.88 \%$ \\
\hline
\end{tabular}

Regarding indication of cesarean section majority of cases were operated due to obstructed labour i.e 154(27.94\%), 35 (6.35\%) cesarean section were performed due to labour dystocia /non progress of labour, mal-position ,61(11.0\%) were due to fetal distress while $79(14.33 \%)$ were performed due to previous one cesarean section ,59(10.7\%) due to antepartum haemorrhage ,other indication were intrauterine growth restriction ,uncontrolled pregnancy induced hypertension, chorioamnitis in $15(2.72 \%)$, maternal wish was also seen in 18(3.26\%)cases .(Table-II)

\begin{tabular}{|l|c|c|}
\hline \multicolumn{1}{|c|}{ Indication } & Number & Percentage \\
\hline Obstructed labour & 154 & $27.94 \%$ \\
\hline BOH & 67 & $12.15 \%$ \\
\hline $\begin{array}{l}\text { Dystocia / non progress of } \\
\text { labour, malposition }\end{array}$ & 35 & $6.35 \%$ \\
\hline Fetal distress & 61 & $11.0 \%$ \\
\hline APH & 59 & $10.7 \%$ \\
\hline $\begin{array}{l}\text { Malpresentation (Breech / } \\
\text { Transverse lie) }\end{array}$ & 26 & $4.71 \%$ \\
\hline Eclempsia & 79 & $14.33 \%$ \\
\hline Previous 1 cesarean section & 15 & $2.72 \%$ \\
\hline $\begin{array}{l}\text { Other (IUGR, uncontrolled } \\
\text { PIH, Chorioamnitis) }\end{array}$ & 18 & $3.26 \%$ \\
\hline Maternal wish & & \\
\hline
\end{tabular}

Most common complication after cesarean section was postpartum hemorrhage i.e $38(6.89 \%)$, second one was fever while other complication were wound infection, urinary tract infection and anesthesia complication. Regarding fetal complication early neonatal death were 103(18.69\%), Fresh still birth were $15(2.72 \%)$,Macerated intrauterine death were $12(2.17 \%)$ while alive born were $421(76.40 \%)$. (Table-III) 


\begin{tabular}{|l|c|c|}
\hline \multicolumn{1}{|c|}{ Maternal complication } & Number & Percentage \\
\hline Fever & 32 & $5.80 \%$ \\
\hline Wound Infection & 15 & $2.72 \%$ \\
\hline PPH & 38 & $6.89 \%$ \\
\hline Anesthesia complication & 4 & $0.72 \%$ \\
\hline UTI & 12 & $2.17 \%$ \\
\hline Fetal complication & 421 & $76.40 \%$ \\
\hline Born alive & 15 & $2.72 \%$ \\
\hline Fresh still birth & 12 & $2.17 \%$ \\
\hline Macerated IUD & 103 & $18.695 \%$ \\
\hline Earl neonatal death & \multicolumn{2}{|c|}{} \\
\hline \multicolumn{2}{|c|}{ Table-III. Maternal and fetal complication } \\
\hline
\end{tabular}

\section{DISCUSSION}

This study was conducted to assess the indication of cesarean section in our setup. Cesarean section rate in our study was $36.20 \%$ which was quiet high in comparison with other studies. Cesarean section rate were $18-23 \%$ in USA and $\mathrm{Uk}^{8}$. Main reason of this increased cesarean section rate is because it is tertiary care hospital and majority of complicated patients are referred here, after receiving full trial of labour in local maternity clinics. So obviously the cesarean section rate will be increased. Also majority of patient in this study were unbooked i.e. $76.58 \%$ this is due to lack of awareness about antenatal care in low socioeconomic ${ }^{9}$.

Major indication of cesarean section in our study was obstructed labour 27.94\%. Majority of the population situated in the vicinity of Isra are uneducated and have lack of awareness, they think that delivery is natural process and they prefer for vaginal delivery.

Another common indication of cesarean section seen in our study was previous cesarean section which was $14.33 \%$. Previous cesarean section is one of the most common indication for performing repeat cesarean section which is also seen in other studies ${ }^{10}$. A study conducted queta ${ }^{11}$ reported in the results the frequency of repeat cesarean section is $15.57 \%$ which is comparable with our result $\mathrm{s}$. Primary cesarean section should be avoided if possible because it affect the future mode of delivery. Trial of scar should be given if not contraindicated.

Fetal distress was seen $11 \%$ of patient in our study. Other common reason of cesarean section APH, Dystocia, non progress of labour. Result of there were similar to other study conducted b y Lin $\mathrm{Hc}^{12}$.

Cesarean section is considered as last resort for delivery. In this study all cesarean section were done with specific indication where vaginal delivery is not possible.

Despite remarkable improvement in safety of anesthesia and surgical techniques. Cesarean section increases the risk of maternal morbidity and mortality as compare to vaginal delivery ${ }^{13}$. The common cause of morbidity after cesarean section in our study was postpartum haemorrhage and wound infection.

Perinatal mortality depend upon the age of gestational age and indication of cesarean section. Regarding fetal outcome following cesarean section $76.58 \%$ were born alive. While $23.58 \%$ babies were lost, perinatal mortality which is high when compared with other study ${ }^{14,15}$.

Main reason of this increase cesarean section rate in our setup is lack of awareness about health care system and late referral to tertiary care hospital.

\section{CONCLUSIONS}

The rate of cesarean section in our study was high. The commonest indication of cesarean section was obstructed labor and majority of the patients belongs to low socioeconomic and were unbooked. Common complication was PPH, fever from maternal side while fetal complication was early neonatal death.

\section{Copyright $@ 25$ Mar, 2013.}




\section{REFERENCES}

1. Tamapakoudis p, Assimakopoulos E, Grimibizis G, Zafrakas M, Tampakoudis G, MantalenakisS, etal. Cesarean section rates and indications in Greece: data from a 24-year period in a teaching hospital. Clin ExpobstGynecol 2004; 31:289-92.

2. Lee SI, Khang HY, Lee MS. Women's attitudes toward mode of delivery in: a society with high cesarean section rates. Birth 2004; $31: 108-16$.

3. Bottoms SF, Rosen MG, Sokol RJ. The increase in cesarean birth rate. NEng J Med 1980;559-63.

4. Shaheen F, Vaginal birth after cesarean section: a 3 years study. PakJ Obst Gynaecol 1997;103(3):18-21.

5. C-section rates around globe at epidemic level. The Associated Press; msn Canada news 2010. Available athttp//.www.msnbc.msn.com/id/34826186/.

6. World Health Organization. Appropriate technology for birth. Lancet 1985;2(8452):436-7.

7. Gulfareen $\mathrm{H}$, Nishat $\mathrm{Z}$, Aftab AM, Ambreen $\mathrm{H}$ Frequency and indication of cesarean section section at tertiary care hospital. Pak J Med Sci 2009; 25:786-91.

8. Leitch CR. Walkers JJ. Cesarean section rates. BMJ 1994; 308: 133-4.

9. Notozon FC, Plack PJ, Taffel SM. Comparison of national cesarean section rates. $N$ Engl $J$ Med 1987;316:386.

10. Cecatti JG, Pires HM, Faundes A, Duarte Osis MJ. Factor associated with vaginal birth after previous cesarean section Brazilian women. Rev Panam Saludpublica 2005; 18: 107-13.

11. Stafford RS. Cesarean section use and source of payment: An analysis of California hospital discharge abstracts. Am J Public Health 1990;80:313-15.

12. Yousf R, Baloch SN. An audit of cesarean section. Pak J Med Res 2006;45:28-31.

13. Lin $\mathrm{HL}$, Sheena TL, Tang CH, Kao S, Association between maternal age and the likehood of cesarean section. A population based multivariation logistic regression analysis. Acta Obstet Gynecol scand 2004;83:1178-83.

14. Boyee PM ,Todd AT. Increased risk of postnatal depression after emergency cesarean section. Med J Aust 1992; 156: 172-74.

15. O'Driscouk, Foly M. Correlation of decrease in perinatal mortality and increase in cesarean section rates. Obstel Gynecol 1983;61:1.

16. Glazener CMA, Abdulla M, Stroud P, Naji S, Templeton At, Russllell IT. Postnatal maternal morbidity; extentcauses, prevention and treatment. $\mathrm{Br}]$ Obstel gynecol 1995;102;286-7.

\section{AUTHOR(S):}

1. DR. QAMARUNISSA

MBBS, FCPS

Department of Obstetrics \& Gynaecology,

Aga Khan Maternity \& Child Care Hospital Sindh, Pakista.

2. DR. FKHARUNISSA

MBBS, FCPS

Instructor

Department of Obstetrics \& Gynaecology,

Aga Khan Maternity \& Child Care Hospital

Hyderabad-Sindh, Pakistan.
Correspondence Address:

Dr. Qamarunissa

Department of Obstetrics \& Gynaecology,

Aga Khan Maternity \& Child Care Hospital Hyderabad

Sindh, Pakistan.

qamarunissanoonari@yahoo.com 


\section{PREVIOUS RELATED STUDIES}

Choudry A, Nausheen J, Afsheen A, Malik A, Masood S. RISING CAESAREAN SECTION RATE; MAKING SENSE OF IT, IS IT UNAVOIDABLE? Prof Med Jour 17(1) 78-83 Jan, Feb, Mar 2010.

Ali S.H, Saleem N, Agha F. CAESAREAN SECTION; SURGICAL TECHNIQUES (Original) Prof Med Jour 17 (3) 505-512 Jul, Aug, Sep 2010.

Kausar R, Yasmeen L. ELECTIVE CAESAREAN SECTION; SHORT ANTIBIOTIC PROPHYLAXIS VERSUS PROLONGED ANTIBIOTIC THERAPY (Original) Prof Med Jour 17(2) 304-307 Apr, May, Jun 2010.

Amin S, Roohi M. CAESAREAN SECTION IN BIRTH PRESENTATION (Original) Prof Med Jour 9(1) 24-28 Jan, Feb, Mar 2002

Hassan S, Javaid K.M, Tariq S. EMERGENCY CAESAREAN SECTION; COMPARATIVE ANALYSIS OF PROBLEMS ENCOUNTERED BETWEEN PATIENTS OF ELECTIVE CAESAREAN SECTION AND PATIENT FOR WHOM ELECTIVE CAESAREAN SECTION WAS PLANNED BUT ENDED UP IN EMERGENCY (Original) Prof Med Jour 15(2) 211-215 Apr, May, Jun 2008.

Kashif S, Mansoor M, Tariq R, Tahira T. VAGINAL BIRTH AFTER CAESAREAN SECTION; TO EVALUATE FACTORS FOR SUCCESSFUL OUTCOME (Original) Prof Med Jour 17(4) 665-669 Oct, Nov, Dec 2010.

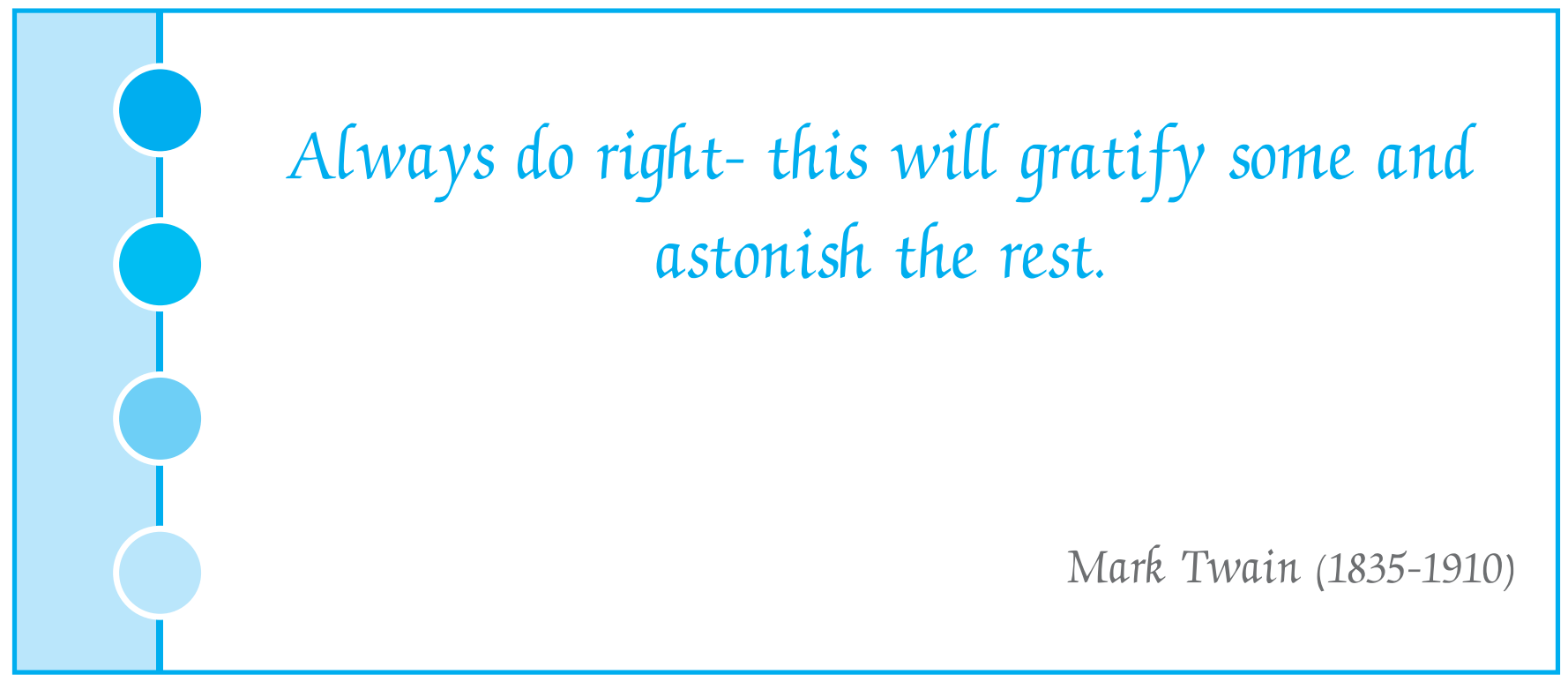

